\title{
PELUANG DAN TANTANGAN JURNALISME PERJALANAN \\ DALAM MENGKOMUNIKASIKAN PARIWISATA
}

\author{
Agustin Diana Wardaningsih \\ Fakultas Ilmu Sosial dan Ilmu Politik, Universitas Pelita Harapan, Indonesia \\ agustin.wardaningsih@uph.edu
}

Diterima : 15 Maret 2020; Review : 10 juni 2020; Direvisi Author : 17 juli 2020; Terbit : 14 Agustus 2020

\begin{abstract}
Abstrak
Travel journalism is one of today's journalistic developments. The main objective of this research is to analyze the concept of travel journalism, to see the opportunities and challenges faced in communicating Indonesian tourism. The development of the tourism industry increases the need for tourism communication as one of human activities in conveying information about travel to an area or tourist attraction. So far, tourism communication activities carry out as a means of promotion of tourism objects so that it makes people interested to visit. But often forget the completeness of infrastructure and the readiness of local communities to receive tourist visits. This is one of the duties and responsibilities of travel journalism to provide a complete and complete picture in accordance with the facts and data in the field related to certain places or attractions. This research is a qualitative descriptive with literature study, using reference books and other sources to strengthen the results of the analysis. Descriptive research was conducted to describe the concept of travel journalism from literature studies so that there are opportunities for tourism communication, especially in Indonesia, as well as to see what challenges travel journalists will face in communicating tourism in Indonesia. The result of the research is that the challenges faced are the development of technology which makes it easy for everyone to produce writing, while it requires standardization and norms writing in travel journalism. Another challenge is media industry commercialization that clashes with journalistic ethics. The opportunity is adaptation, innovation and creativity, as well as the vast area of Indonesia, which can be explored and communicated to the public through the concept of travel journalism
\end{abstract}

Keywords: travel journalism, mass media, communication, tourism

\section{PENDAHULUAN}

Manusia diciptakan Tuhan sebagai mahluk sosial, yang secara alami harus berinteraksi dengan orang lain. Dalam proses interaksi tersebut, manusia mempunyai keinginan untuk berpetualang, dan menemukan hal baru sebagai salah satu bagian dari pengalaman hidup. Itu sebabnya, manusia suka sekali melakukan perjalanan, berpindah dari satu tempat ke tempat yang lain. Selain mencari pengalaman yang berbeda, motivasi lain dalam melakukan perjalanan adalah untuk berdagang atau berbisnis, menemukan daerah baru, berkenalan dengan orang 
baru, dan juga sebagai wujud aktualisasi diri.

Sejarah manusia melakukan perjalanan dimulai dari manusia pertama Adam dan Hawa yang diusir keluar dari Taman Eden, sehingga mereka berpindah tempat ke lokasi yang baru. Selain itu ada sejarah Bangsawan Persia yang mengarungi lautan luas untuk berkelana dan menaklukkan daerah yang ditemui agar sekembalinya ke Persia bisa disebut sebagai Pahlawan. Banyak tokoh-tokoh ternama seperti Marcopolo, Vasco Da Gama, Laksamana Ceng Ho menemukan daerah baru untuk imigrasi penduduk sehingga meluas ke seluruh bumi. Juga ada perjalanan dagang yang dilakukan Portugis, Belanda, dan negara Eropa lain yang sampai ke Indonesia, bahkan karena tertarik dengan kekayaan hasil bumi Indonesia, akhirnya dari berdagang kemudian menjajah.

Seiring dengan perkembangan teknologi dan kemudahan transportasi, motivasi orang dalam melakukan perjalanan juga semakin berkembang. Bukan hanya mencari pengalaman menjelajah daerah baru atau urusan dagang, tetapi berkembang menjadi Pariwisata. Definisi Pariwisata adalah kegiatan manusia yang melakukan perjalanan dan tinggal di daerah tujuan di luar lingkungan kesehariannya, baik untuk keperluan pribadi atau kepentingan bisnis (wto.org). Pariwisata juga didefinisikan sebagai perjalanan untuk tujuan mendapatkan hiburan, mengetahui sesuatu, menikmati istirahat, memperbaiki kesehatan, menunaikan tugas, dll (Spillane, 1994 : 20). Jadi motivasi orang berwisata pun bisa beragam dari mulai sekedar melarikan diri sejenak dari kesibukan aktivitas rutin sebagai bentuk relaksasi, bermain menghibur diri. Orang juga berwisata bersama baik dengan keluarga atau pasangan, untuk tujuan mempererat hubungan keluarga dan juga harmonisasi hubungan suami istri. Bahkan wisata juga dilakukan hanya sekedar aktualisasi diri, menjaga gengsi, memenuhi harapan pribadi atau benar-benar untuk kepentingan pribadi.

Saat melakukan perjalanan wisata, banyak orang mendokumentasikan perjalanan yang dilakukan baik dalam bentuk foto, video, maupun tulisan. Selain sebagai kenang-kenangan perjalanan wisata yang dilakukan, banyak orang menggunakan foto dan tulisan sebagai media bercerita kepada orang lain tentang kunjungan wisata tersebut. Catatan perjalanan ini menjadi kisah yang bisa menarik orang membaca, dan kemudian 
tertarik berkunjung atau melakukan perjalanan serupa. Catatan perjalanan sudah dilakukan orang sejak jaman dahulu kala. Catatan perjalanan masa lampau bahkan bisa menjadi bagian dari sejarah manusia. Salah satunya adalah buku harian dari pengembara Maroko di tahun 1300an yaitu Ibnu Battutah yang dianggap sebagai catatan perjalanan dunia terlengkap di masa itu (Arismunandar, 2010). Walau banyak mengandung kisah fiksi, namun Ibnu Battutah mengklaim bahwa apa yang ditulis merupakan apa yang dilihat dan dialaminya sendiri. Termasuk di dalamnya ada kisah kemakmuran kerajaan Samudra Pasai (sekitar daerah Sumatera) yang disinggahinya. Selain itu ada catatan perjalanan Marcopolo dari Eropa ke Asia yang berhasil merekam keberadaan Jalur Sutra, bahkan berkembangnya kerajaan di Jawa masa itu. Irwansyah (2019) menyebutkan bahwa catatan perjalanan yang abadi yaitu yang merekam perubahan sosial, keresahan masyarakat, pertumbuhan bahasa, potret budaya, kondisi perekonomian, hingga pergolakan politik. Ide dasar dari catatan perjalanan adalah menciptakan jembatan dari tempat yang dikunjungi (Place) dan rumah tinggal (home).

Kegiatan membuat catatan perjalanan semakin berkembang seiring dengan perkembangan industri pariwisata di dunia. Di Indonesia, sejak dicanangkan 10 Destinasi Pariwisata Prioritas yaitu Danau Toba, Candi Borobudur, Tanjung Lesung, Tanjung Kelayang, Wakatobi, Labuhan Bajo, Kepulauan Seribu, maka ada harapan bahwa sektor pariwisata bisa mendongkrak devisa negara (Setyawan, 2019). Catatan perjalanan menjadi salah satu sarana untuk melakukan promosi pariwisata. Orang membuat catatan perjalanan bukan lagi untuk konsumsi pribadi, tetapi sebagai sarana berbagi informasi kepada orang lain terutama lewat media sosial yang dimiliki. Pertumbuhan sektor

Pariwisata juga memunculkan cara baru dalam menulis dan memberikan informasi perjalanan yaitu lewat media massa dan internet. Lewat media cetak salah satunya lewat rubrik jalan-jalan Kompas, atau lewat media TV dengan program jelajah Trans TV, My Trip My Adventure Trans, dll, serta ada detiktravel dan kompastravel sebagai referensi dari media internet. Banyak juga bermunculan travel blooger dengan berbagi catatan perjalanan lewat blog seperti nakedtraveler.com milik Trinity sebagai salah satu pelopor travel blog di Indonesia sejak tahun 2015. 
Dengan trend social media dan blogging, maka di sektor pariwisata banyak sekali travel blogger lokal yang tulisan dan foto perjalanannya menghiasi internet (Hidayat, 2014). Selain itu, Priyatna dalam Hidayat (2014) juga menyebutkan bahwa $80 \%$ orang Indonesia melakukan riset online sebelum melakukan wisata. Sehingga muncul banyak sekali orang yang kemudian membuat catatan perjalanan baik dalam bentuk tulisan maupun foto-foto yang mereka unggah pada media sosial yang mereka miliki. Dan kemudian banyak orang menyebut diri mereka sebagai travel writer.

Travel Writing atau catatan perjalanan biasanya fokus pada cerita tentang lokasi wisata yang dikunjungi (tiede, 2017). Kisah ini jika diceritakan ulang akan menjadi salah satu media promosi agar orang mau beramai-ramai berkunjung ke daerah tersebut. Inilah yang membedakan Travel Writing dan Travel Journalism, yang untuk selanjutnya oleh peneliti akan disebut sebagai Jurnalisme perjalanan. Tiede (2017) menyebutkan 'Travel Journalism is not travel writing'. Jurnalisme perjalanan menulis untuk memberikan informasi kepada wisatawan yang benar-benar memiliki keinginan untuk lebih tahu secara akurat bukan saja tentang lokasi wisata tetapi juga kebudayaan dan orang-orang di sekitarnya. Sementara, Travel Writing lebih terlihat seperti menyampaikan informasi yang membentuk citra yang baik, sebagai iklan untuk menarik wisatawan berkunjung. Contohnya, travel writer akan menulis tentang perjalanan ke daerah Baduy seperti sebuah buku panduan perjalanan menuju daerah Baduy dan situasi sekitarnya, transportasi menuju ke daerah Baduy, kawasan hutan yang harus dilalui, melewati jembatan akar gantung yang indah, hingga sampai ke komunitas masyarakat Baduy tinggal. Sementara Jurnalis Perjalanan juga menceritakan tentang situasi alam, proses menuju ke sana, tetapi menggabungkannya dengan kisah tentang adat istiadat setempat, yang hanya bisa didapat lewat interaksi dengan masyarakat setempat. Bahwa ada aturan kalau pengunjung hanya boleh sampai pada kawasan Baduy luar, dan hanya orang tertentu, terutama lakilaki yang diperbolehkan masuk sampai kawasan Baduy dalam. Tata cara berpakaian, peralatan makan yang sederhana dari batok kelapa, tidak ada listrik, sampai pada tata cara yang masyarakat Baduy lakukan untuk menghargai alam ciptaan Tuhan.

Jurnalisme perjalanan fokus liputannya pada perjalanan dalam arti luas. 
Fokus cerita bukan saja menggambarkan keindahan sebuah obyek wisata tetapi juga bagaimana dengan orang sekitarnya (Arismunandar, 2010). Inilah konsep yang sebetulnya sudah dilakukan oleh para tokoh sejarah tempo dulu dengan catatan perjalanannya seperti yang dilakukan oleh Ibnu Battuta dan Marcopolo. Sementara, konsep jurnalisme perjalanan di Indonesia sudah dimulai sejak permulaan abad ke-20, salah satunya oleh alm. Adinegoro, wartawan senior Indonesia masa itu (Irwansyah, 2019). Karya Jurnalisme Perjalanan Adinegoro mengisahkan tentang perjalanannya dengan kapal mengunjungi negara-negara di Eropa, dimuat di majalah Pandji Poestaka, dan diterbitkan ulang dalam buku 3 jilid oleh Balai Pustaka.

Konsep Jurnalisme Perjalanan juga muncul dalam blog Agustinus Wibowo. Bila travel writer lain menulis tentang kunjungan dan keindahan negara yang sering dijadikan kunjungan wisata, tetapi Agustinus Wibowo (travel blogger dan penulis) justru tertarik berkunjung ke negara-negara yang memiliki kesan tak aman dan jarang dijadikan kunjungan wisata. Perjalanan pertamanya adalah mengunjungi Afganistan yang sedang berperang (agustinuswibowo.com). Blog Agustinus Wibowo memuat konsep
Jurnalisme Perjalanan, karena tidak hanya memotret keindahan tempat wisata yang dikunjungi, tetapi juga mengisahkan interaksi dengan warga lokal sehingga mampu menangkap suka duka, mimpi, dan harapan warga sekitar. Banyak juga travel blog lain yang kemasannya bukan hanya sekedar keindahan wisata tetapi juga interaksi dengan penduduk setempat, seperti naked-traveler.com, duaransel.com, backpackstory.me. Travel Blogger menjadi aktor utama dalam promosi pariwisata Indonesia (Tazbir, 2015). Namun perlu dikemas dengan konsep Jurnalisme perjalanan agar bisa secara akurat menghadirkan informasi tentang sebuah obyek wisata.

Jurnalisme perjalanan sejalan dengan konsep jurnalistik dalam mengemas informasi berdasarkan fakta, keakuratan, dan riset maka harus mampu menangkap realitas nyata yang ada dalam sebuah obyek wisata tertentu. Sunarto, (2015) menyebutkan bahwa Jurnalistik perjalanan memiliki konsep perjalanan liburan yang ditulis sesuai dengan kaidah jurnalistik, ada etika dan objektivitas. Ada standar yang berbeda antara jurnalisme perjalanan dan catatan perjalanan lain. Travel wiriting more often includes fictional elements and other literary lincense that would not be accepted in traditional news media. And 
travel journalism is bound to professional ideals of journalism in its representation of distant places and people (Hanusch \& Fursich, 2014: 6). Namun, Hanusch \& Fursich (2014: 70) juga mengakui bahwa konsep jurnalisme perjalanan masih dipandang sebelah mata, karena berada di area abu-abu antara sebuah karya hiburan (entertainment) atau bentuk dari berita (news). Di satu sisi, jurnalisme perjalanan menjadi penting sebab menawarkan informasi kepada masyarakat bagaimana memahami dan mempelajari kebudayan orang lain, terutama dalam menghadapi era globalisasi(tiede, 2017). Sunarto (2015) menyatakan bahwa jurnalisme perjalanan terbukti efektif membantu pengembangan pariwisata Indonesia.

Untuk membantu pengembangan pariwisata di Indonesia, tentu bukan hal yang mudah dalam kinerja jurnalis perjalanan. Ada sisi dilematis yang akan dihadapi para jurnalis perjalanan, karena ada tuntutan memberikan informasi yang baik untuk mempengaruhi peningkatan kunjungan wisata, dan di satu sisi secara etis harus menyampaikan informasi yang

\section{METODOLOGI PENELITIAN}

Penelitian ini adalah penelitian kualitatif dengan menggunakan konsep studi pustaka, menggunakan referensi akurat sesuai dengan kondisi nyatanya. Hal ini seolah berbanding terbalik dengan komunikasi pariwisata.

Dalam komunikasi pariwisata merupakan segala upaya yang dilakukan berbagai pihak untuk mengkomunikasikan pariwisata di sebuah daerah tertentu kepada masyarakat luas. Tujuan utama komunikasi pariwisata adalah untuk mengenalkannya kepada masyarakat sehingga tertarik untuk berkunjung.

Tentu menjadi tantangan tersendiri bagi perkembangan jurnalisme perjalanan untuk bisa menyampaikan informasi secara akurat tentang sebuah obyek wisata, dengan konsep komunikasi pariwisata menyampaikan pesan wisata yang baik. Sehingga tujuan dari penelitian ini untuk melihat tantangan apa yang akan dihadapi pada saat konsep jurnalisme perjalanan dipakai untuk mengkomunikasikan pariwisata khususnya di Indonesia, serta melihat apakah ada peluang mengembangkan pariwisata khususnya di Indonesia dengan mengkomunikasikannya dalam kerangka jurnalisme perjalanan.

buku-buku dan sumber-sumber lainnya untuk memperkuat hasil analisa. Penelitian kualitatif ini menggunakan analisa deskriptif yang memberikan 
gambaran menyeluruh, sistematis, terstruktur, dan jelas dalam penjelaskan pertanyaan penelitian. Penelitian Deskriptif dilakukan untuk menjabarkan konsep jurnalisme perjalanan dari studi literatur agar terlihat adanya peluang bagi komunikasi pariwisata terutama di Indonesia, serta melihat tantangan apa yang akan dihadapi para jurnalis perjalanan dalam mengkomunikasikan pariwisata di Indonesia.

Pengumpulan data dilakukan
dengan studi pustaka dengan
mengumpulkan buku-buku, jurnal, dan
sumber-sumber lain yang sesuai dengan
masalah dan tujuan penelitian. Penelitian
dilakukan dengan membandingkan satu
sumber dengan sumber yang lain dalam
kerangka teoritis sehingga bisa menjawab

\section{HASIL DAN PEMBAHASAN}

Jurnalistik merupakan sebuah kegiatan menghimpun berita, mencari fakta, dan melaporkan peristiwa sehingga menjadi produk berita (news) (McDougal, 1992). Journalism merupakan pengembangan dari Journal yaitu catatan harian, jadi jurnalis atau wartawan merupakan orang yang melakukan pekerjaan-pekerjaan jurnalistik. Dan dari definisi di atas, maka Jurnalisme Perjalanan merupakan sebuah kegiatan mengumpulkan, menghimpun berita, permasalahan yang ada. Selain itu penelitian ini didukung oleh observasi yang dilakukan oleh peneliti dalam bidang jurnalisme perjalanan. Observasi dilakukan dengan melakukan kunjungan lapangan ke beberapa obyek wisata di sekitar Jabodetabek seperti kawasan pasar lama Tangerang, pasar bunga Rawa Belong, Kota Tua, dan daerah lain di Indonesia seperti Yogyakarta serta Lombok.

Observasi juga mengumpulkan beberapa bukti dokumentasi baik dari buku, media cetak, dan media elektronik, seperti media travel seperti Kompas Travel, Detik Travel, juga Blog yang ditulis para travel blogger Indonesia seperti NakedTraveller.com, AgustinusWibowo.com, program Jejak Petualang TransTV.

mencari fakta, dan melaporkan peristiwa pariwisata. Hasil karya jurnalistik akan muncul lewat media massa. Dan karya jurnalisme perjalanan muncul pada media massa seperti koran dan majalah (kompas dengan rubrik jalan-jalan), media elektronik TV dengan jejak petualang (Trans TV), 100 hari keliling Indonesia (Kompas TV), MyTrip My Adventure (Trans), dan lewat media baru internet 
seperti Detik Travel, Kompas Travel, dan juga travel blog.

Berikut ini adalah beberapa contoh konsep jurnalisme perjalanan yang tergambar dalam berbagai media. Yang pertama adalah tampilan dari website Kompas Travel dengan liputan mengenai 'Jalan-jalan ke Pasar Bunga Rawa Belong, Buka 24 Jam di Jakarta'. Artikel ini dipublikasikan pada 5 Februari 2020. Pasar Bunga Rawa Belong bisa menjadi salah satu destinasi wisata diJakarta. Peneliti melakukan observasi langsung ke Pasar Bunga Rawa Belong setelah tertarik dengan tulisan yang disampaikan di Kompas Travel. Dan menemukan bahwa informasi yang disampaikan lewat tulisan artikel KompasTravel akurat sesuai dengan apa yang disaksikan langsung. Dalam liputan mengenai pasar Rawa Belong, ada beberapa artikel yang dipublikasikan. Di bawah ini merupakan salah satu artikel yang membahas mengenai Pasar Rawa Belong sebagai salah satu pasar bunga terbesar di Indonesia, bahkan di Asia Tenggara, dengan aktivitas nya selama 24 jam. Kompas Travel secara detail membahas beragam bunga yang dijual beserta harganya, dan interaksi dengan pedagang untuk mengetahui nama dan makna dari bunga-bunga yang dijual.

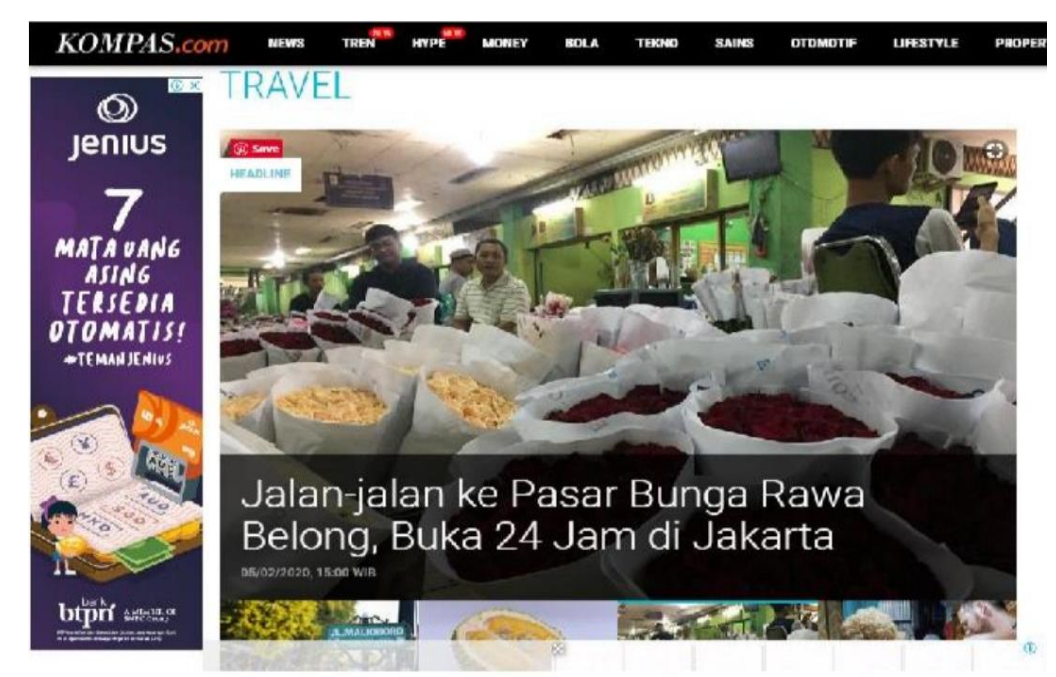

Sumber : KompasTravel (februari, 2020)

Pada bagian lain di kompastravel.com juga membahas secara detail moda transportasi apa saja yang bisa digunakan untuk menuju kawasan Rawa Belong ini. Hal ini bisa menjadi referensi bagi wisatawan yang ingin melihat konsep pasar 
tradisional yang menjual barang khusus yaitu bunga. Pada contoh lain di bawah ini adalah salah satu produk jurnalistik perjalanan di media elektronik televisi.

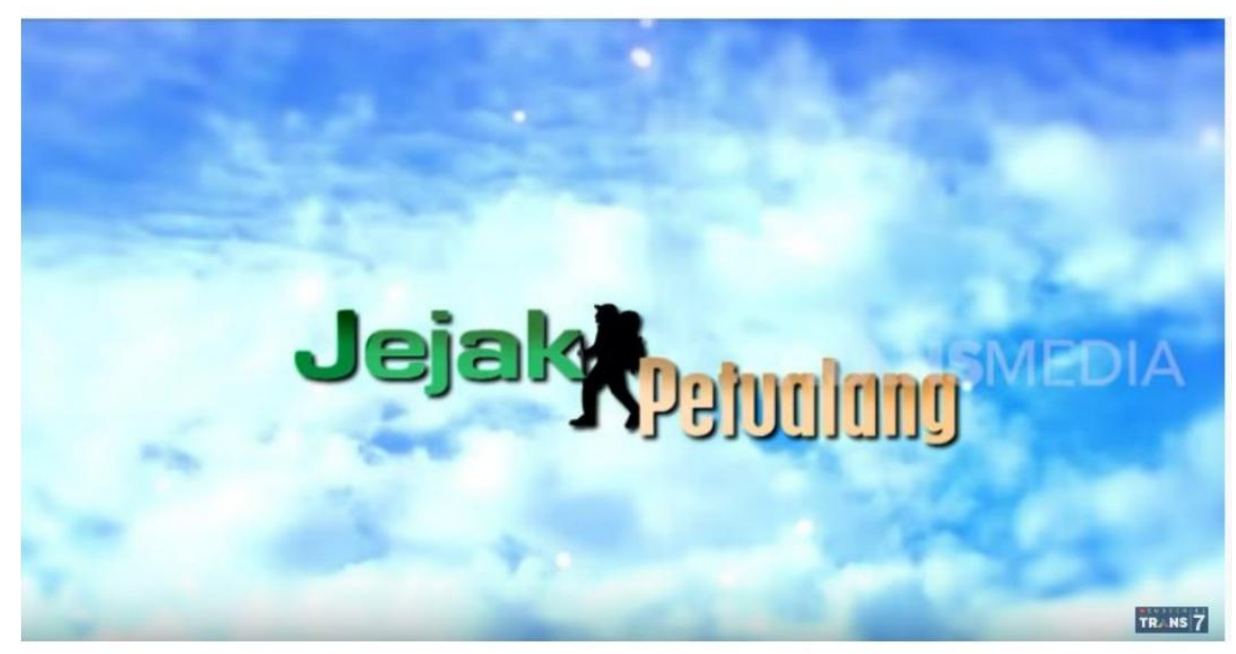

Sumber : Screen Capture Youtube Jejak Petualang Trans7

Jejak Petualang merupakan salah satu program televisi Trans 7 berupa tayangan dokumenter perjalanan. Program ini merupakan salah pelopor konsep jurnalisme perjalanan lewat media televisi. Program ini tayang sejak tahun 2002, dengan konsep berpetualang menjelajahi gunung, lautan, pantai, kawasan pedalaman, dan mengisahkan kesulitan yang dihadapi untuk bisa menikmati keindahan alam lokasi yang

Dan sebagai satu contoh blog yang juga memuat konsep jurnalisme perjalanan adalah naked traveller dari penulis trinity. Blog ini juga dianggap sebagai salah satu pelopor dari travel blog karena ada sejak dikunjungi(jejakpetualangtrans7). Bukan hanya menggambarkan sulitnya medan yang ditempuh untuk bisa sampai pada obyek yang dituju, terkadang ada interaksi dengan masyarakat setempat untuk bersama menuju ke obyek wisata. Jejak Petualang sendiri saat ini telah dikembangkan dalam beberapa variasi program, namun tetap konsisten dengan host nya adalah perempuan.

tahun 2005, dan dari tulisan di dalam blog ini juga sudah diterbitkan buku-bukunya. The Naked Traveler merupakan plesetan dari Nekad, karena konsep tulisannya benar-benar menampilkan apa adanya pengalaman yang ditemui setelah 
menjelajah hampir semua daerah di Indonesia, dan sekitar 80 negara (tripzilla.id, 2017). Dalam setiap tulisannya, Trinity bukan saja menggambarkan keindahan daerah yang dikunjunginya, namun juga suka duka menempuh perjalanan, serta karakteristik penduduk setempat, karena selalu ada tulisan tentang interaksinya dengan masyarakat setempat.

\section{Naked Traveler

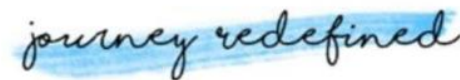

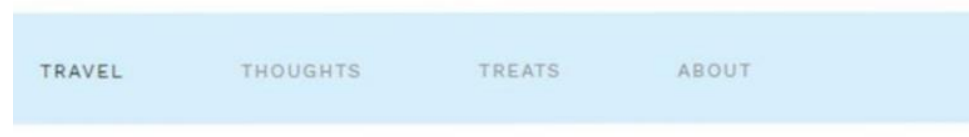
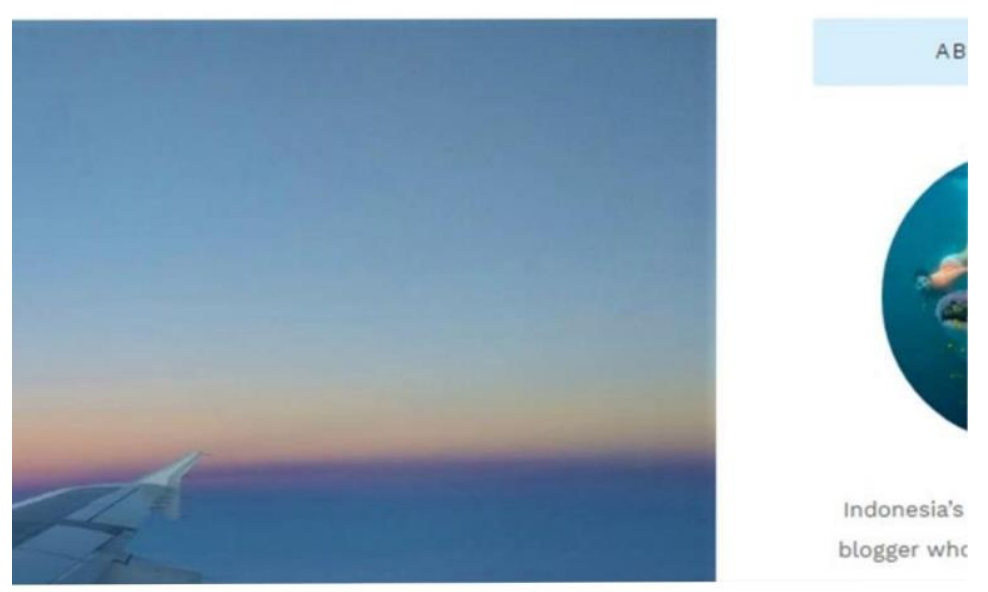

Sumber : Screen Capture Blog Naked Traveller.com

Dari 3 media yang memuat konsep jurnalisme perjalanan, memuat konsep yang disampaikan oleh Hanusch \& Fursich (2014: 11), tentang perbedaan kegiatan yang dilakukan tourist, travel writing, dan travel journalism. Kegiatan yang dilakukan turis adalah berkunjung ke satu daerah/ obyek wisata, menikmati keindahan dan keunikannya, menceritakannya kepada orang lain baik langsung atau lewat media sosial. Sementara travel writing, berkunjung ke satu daerah/ obyek wisata, menikmati keindahan dan keunikan daerah tersebut, kemudian membuat catatan perjalanan yang secara rutin ditulis bisa lewat blog atau media sosial lainnya. Dan yang terakhir Jurnalisme Perjalanan (travel journalism), kegiatannya berkunjung ke sebuah obyek wisata bukan hanya sekedar 
menikmati keindahan dan keunikannya, tetapi menggali lebih dalam informasi lebih dalam informasi termasuk mengenai budaya, geografi, seni, etika, bahkan filosofi dari setiap obyek wisata yang dikunjungi. Dan tidak lupa juga seorang jurnalis perjalanan akan berinteraksi dengan masyarakat sekitar sehingga bisa menggambarkan secara detail kisahnya dengan akurat.

Profesi sebagai Jurnalis Perjalanan bermakna bukan pekerjaan amatir, tetapi ada standarisasi yang perlu diikuti, membutuhkan pelatihan khusus, dan ada norma yang mengatur perilakunya dengan titik berat tidak melupakan interaksi dengan masyarakat. Namun, meningkatnya jumlah penulis amatir yang memberikan informasi perjalanan secara online, menjadi tantangan terbesar bagi Jurnalisme Perjalanan sebagai profesi (Hanusch \& Fursich, 2014: 8). Tulisan tentang perjalanan wisata bisa dibuat dengan mudah oleh penulis amatir, kemudian mengunggahnya di dalam kolom review web seperti TripAdvisor, atau mengunggah foto di Instagram atau Flickr. Karya jurnalisme perjalanan juga bisa diproduksi oleh travel blogger yang berpengaruh, yang juga menghasilkan tulisan dan konten visual bukan saja untuk diunggah di blog yang dimiliki tetapi bahkan mengisi kolom atau program pada media massa cetak maupun elektronik. Hanusch \& Fursich (2014: 9) menyatakan ada paradoxical situation saat kehadiran teknologi baru memberikan kemudahan bagi seseorang untuk memproduksi konten perjalanan untuk masyakarat, di satu sisi justru menyulitkan bagi seseorang yang ingin menjadikan jurnalisme perjalanan sebagai satu profesi.

Tantangan bagi profesi Jurnalis Perjalanan, justru menumbuhkan peluang terutama bagi seseorang yang ingin berprofesi sebagai Jurnalis Perjalanan. Bekal latar belakang pendidikan sebagai jurnalis menambah kemampuan profesional untuk menghasilkan tulisan berkualitas jurnalistik. Dengan fokus pada pengembangan profesi Jurnalis Perjalanan, bisa menghasilkan karya yang menjadi acuan bagi para penulis amatir. Selain karya berupa tulisan atau produk multimedia bisa dikonsumsi publik lewat media massa, bahkan juga media sosial (online) yang dimiliki. 'Once travel journalists started to create their own online outlets, they became more than just travel journalists, they became publishers' (Barbara in Rosekranz, 2016: 59) Orang akan memiliki kepercayaan kepada seseorang yang secara profesi memang merupakan pakar dalam jurnalisme 
perjalanan daripada penulis amatir. Rekomendasi yang diberikan oleh Jurnalis perjalanan dinilai kredibilitasnya lebih tinggi dari penulis amatir. Hanusch \& Fursich (2014: 8) tidak bisa memberikan jaminan pasti bahwa profesi Jurnalis Perjalanan mampu bertahan, namun perkembangan travel journalism saat ini bisa memberikan kontribusi bagi pekerjaan jurnalistik untuk menghasilkan pendapatan yang lebih tinggi.

Jurnalisme Perjalanan secara profesional diakui sebagai bagian dari Jurnalistik dengan menggabungkan antara konsep jurnalistik dengan travel writing sudah dikenal lewat majalah National Geographic yang berdiri sejak tahun 1988, dan secara komersial konsep travel magazine terbit majalah U.S. Camera and Travel di tahun 1937 (Rosekranz, 2016: 57). Namun perkembangan teknologi media dengan munculnya media online membawa perubahan baru. Banyak koran dan majalah tutup karena kemudahan yang ditawarkan media online lebih menarik banyak orang menggunakannya. Sementara media elektronik seperti radio dan tv juga menghadapi krisis persaingan dalam menyediakan konten yang memiliki rating tinggi sehingga bisa menarik iklan. Krisis yang dihadapi industri media akibat perkembangan teknologi menjadi tantangan berat untuk perkembangan konsep Jurnalisme Perjalanan.

Setiap kali muncul media baru, kata kunci untuk media yang sudah eksis dan ingin tetap eksis adalah adaptasi, inovasi, kreatifitas, atau ketinggalan dan ditinggalkan (Oetama, 2001: 361). Rubrik Kompas Cetak Jalan-jalan, diadaptasi ke dalam rubrik Travel Kompas.com (media online). Media Group seperti Trans Corp juga memiliki program liputan perjalanan baik di Trans TV atau Trans 7, dan secara fokus pada media online lewat DetikTravel. Ini merupakan langkah adaptasi dan inovasi agar tidak ketinggalan. Artinya walau menjadi tantangan, namun peluang untuk berkembangnya konsep Jurnalisme Perjalanan masih terbuka luas lewat media elektronik dan media online.

Masih ada tantangan lain dari industri media pada karya Jurnalistik Perjalanan yaitu komersialisasi media. Industri media merupakan salah satu industri dengan biaya yang besar, tentunya mengharapkan keuntungan yang tinggi. Ada tuntutan bahwa setiap produk atau program yang dihasilkan media massa akan mendatangkan keuntungan. Sisi komersialisasi ini yang bukan hanya mempengaruhi konsep Jurnalisme 
Perjalanan, tetapi juga konsep Jurnalistik pada umumnya (Rozekranz, 2016: 62). Salah satu prinsip utama karya jurnalistik adalah yang menjadi etika para Jurnalis adalah menyampaikan kebenaran, kejujuran, kredibel, dan tidak berpihak. Prinsip etika jurnalistik seperti kejujuran dan kebebasan dari 'konflik kepentingan' akan mudah digantikan saat berhadapan dengan komersialisasi media dan konflik kepentingan pemilik media dalam meraih keuntungan.

Membuat liputan Jurnalisme Perjalanan membutuhkan biaya yang tidak sedikit, dari mulai biaya perjalanan (transportasi) ke destinasi wisata, penginapan, dan pengeluaran lain. Hanusch menyebutkan bahwa 'travelling costs money', sehingga seorang jurnalis perjalanan harus bergantung pada sponsor dari industri pariwisata untuk membiayai perjalanan yang dilakukan (Hanusch \& Fursich, 2014: 12). Sulit untuk menerapkan konsep 'kejujuran' dan bicara apa adanya saat melakukan liputan, karena sulit untuk objektif menyampaikan sesuatu padahal kita diharapkan menyampaikan hal baik oleh sponsor perjalanan kita. Kadang Destinasi Wisata yang dikunjungi dan diliput tidak seindah yang dipromosikan, atau kurang lengkapnya infrastruktur pendukung agar membuat nyaman para wisatawan. Saat hendak menyampaikan informasi, seorang Jurnalis Perjalanan menghadapi dilema. Jika menyampaikan sebenarnya maka justru membuat menjelek-jelekkan destinasi wisata, sementara seharusnya melakukan promosi agar mendatangkan iklan atau paling tidak mendapatkan biaya pengganti perjalanan. Namun secara etika, Jurnalis Perjalanan juga terikat dengan kode etik yang harus memberitakan kebenaran. Ini yang menjadi tantangan terberat untuk menyampaikan informasi yang benar tentang sebuah destinasi wisata.

Ada celah yang bisa menjadi peluang bagi Jurnalisme Perjalanan dalam menghadapi tantangan mengenai etika dan konflik kepentingan. Hanusch \& Fursich (2014: 10) menyebutkan bahwa yang membedakan liputan Jurnalisme Perjalanan dan konsep 'hard news' jurnalistik adalah orientasi pasar. Konsep Jurnalisme Perjalanan mempertimbangkan audience sebagai 'consumer' bukan sebagai 'citizens'. Sebagai warga negara, masyarakat dilindungi secara penuh untuk mendapatkan haknya dalam memperoleh informasi yang akurat, sementara sebagai konsumen, masyarakat membutuhkan informasi yang mereka inginkan atau yang mereka perlukan. Konsep ini memberikan peluang bagi pengembangan Jurnalisme 
Perjalanan dengan mengemas liputannya selain memberikan petunjuk dan saran yang akurat terkait destinasi wisata, dipadukan dengan informasi yang kental unsur hiburan dan relaksasi. Jadi bukan sekedar memberikan informasi sesuai dengan kondisi nyatanya, tetapi membuat kemasannya lebih menarik, menghibur, dan berguna bagi publik.

Dengan segenap tantangan dan peluang yang ada, bagaimana Jurnalisme Perjalanan bisa memberikan informasi pariwisata yang baik kepada masyarakat?. Untuk menjawab hal tersebut, penjelasan selanjutnya akan mengaitkan mengenai Pariwisata, Komunikasi Pariwisata, dan Kontribusi Jurnalisme Perjalanan dalam mengkomunikasikan Pariwisata khususnya di Indonesia.

Pariwisata selalu terkait dengan manusia, karena yang melakukan perjalanan adalah manusia. Setiap orang bisa berpotensi menjadi wisatawan atau pengunjung, dan bisa berpotensi juga sebagai tuan rumah atau host bagi pengunjung atau wisatawan lainnya (teguh, 2020). Pariwisata bukan hanya mencari hiburan tetapi juga meningkatkan kualitas kehidupan. Kita hadir di dunia ini menggunakan alam yang sudah diberikan dan dimiliki oleh kita sehingga wajib mengelolanya dengan sebaik mungkin. Pariwisata adalah suatu proses seseorang pergi sementara menuju tempat lain, selain tempat tinggalnya (Pendit, 2003). Sehingga secara definisi maka Pariwisata adalah suatu kegiatan yang dilakukan sementara waktu di luar rumah, selain untuk menghibur juga untuk meningkatkan kualitas hidup.

Pariwisata adalah bisnis (Teguh, 2020), sehingga menjadi bagian yang tidak terpisahkan dari manusia terutama menyangkut kegiatan sosial dan ekonomi. Di awal abad 20, wisata baru bisa dinikmati sebagian orang yang memiliki uang berlebih, tetapi kini setiap orang bisa dengan bebas melakukan perjalanan wisata. Saat ini, pariwisata merupakan salah satu bisnis modern yang artinya semua produk pariwisata seperti destinasi, ekonomi kreatif, transportasi, perhotelan, atraksi seni, dsb merupakan produk bisnis yang akan menghasilkan pendapatan atau uang. Bahkan Pemerintah Indonesia telah membangun industri pariwisata sebagai salah satu cara untuk menambah pemasukan devisa negara (Pendit, 2003). Pemerintah Indonesia mengklasifikasikan komponen pariwisata ke dalam beberapa komponen penting seperti; (1) industri pariwisata, (2) destinasi pariwisata, (3) pemasaran pariwisata, (4) kelembagaan 
pariwisata (Bungin, 2015: 37). Sehingga perkembangan destinasi wisata disesuaikan dengan kekuatan modal tempat wisata tersebut.

Dengan perkembangan industri pariwisata yang mampu meningkatkan devisa negara, perlu langkah yang tepat untuk mempromosikan wisata Indonesia. Salah satu caranya adalah lewat komunikasi yaitu menyampaikan pesan kepada masyarakat dengan teknik persuasi yang menarik orang untuk berkunjung. Dunia pariwisata sebagai salah satu yang memiliki keberagaman produk memerlukan komunikasi pariwisata, yaitu sebuah kegiatan yang terstruktur dan menyeluruh untuk menyampaikan pesan pariwisata kepada masyarakat luas (Bungin, 2015: 18). Salah satu tujuan komunikasi pariwisata adalah untuk mengkomunikasikan pemasaran pariwisata, mengkomunikasikan aksesbilitas, mengkomunikasikan destinasi kepada para wisatawan. Komunikasi juga berperan menyiapkan konten pesan yang harus disampaikan kepada masyarakat atau wisatawan tentang apa yang semestinya mereka tahu tentang tempat wisata tersebut. Dapat disimpulkan bahwa Komunikasi merupakan proses penyampaian pesan mengenai destinasi wisata, sedangkan pariwisata merupakan penyumbang field tempat wisata, destinasi wisata. Sehingga kedua hal tersebut saling berhubungan dan saling menguntungkan.

Komunikasi Pariwisata bertujuan untuk menyampaikan pesan tentang destinasi wisata kepada masyarakat. Ini merupakan salah satu pekerjaan dari Jurnalisme Pariwisata. Di tengah tantangan dan peluang yang dihadapi sebagai salah satu bagian dari industri media, posisi Jurnalisme Perjalanan juga menghadapi tantangan tersendiri dari industri pariwisata. Jurnalis Perjalanan menghadapi tantangan untuk bisa menyampaikan pesan yang bisa mempromosikan satu destinasi wisata agar mengembangkan industri pariwisata. Tuntutan agar Jurnalis Perjalanan bukan hanya menjadi truth-tellers, juga bisa sebagai mediator yang menjembatani komunikasi antara industri wisata dengan masyarakat. Secara profesi, Jurnalis Perjalanan dituntut mempelajari tentang manusia, dan bagaimana sebuah obyek wisata memiliki pengaruh bagi orang sekitar, memiliki sejarah keterkaitan dan pengaruhnya bagi orang sekitarnya. Komunikasi yang efektif sebagai Jurnalis Perjalanan harus bisa merasakan pengalaman pribadi, melihat, merasakan, mendengarkan, mengalami, dan terlibat di setiap liputan destinasi wisata. Dengan 
demikian Jurnalis Perjalanan bisa mendapatkan peluang untuk mengkomunikasikan pariwisata dengan baik.

Beberapa kajian utama dalam komunikasi pariwisata dibahas oleh Burhan Bungin (2015: 94) yang mencakup beberapa hal. Yang pertama adalah Komunikasi Pemasaran Pariwisata, bidang yang secara utuh membincangkan TCM (tourism communication marketing) dalam konteks teoretis dan praktis yang lengkap, namun tidak spesifik dalam konteks spesialis. Yang kedua adalah Brand Destination, adalah media dan pesan itu sendiri di dalam konteks dan proses komunikasi pemasaran secara umum dan khususnya di dalam konteks pariwisata. Dalam melakukan branding destinasi wisata perlu dilakukan langkah-langkah cermat dan terstruktur serta tidak melupakan warga setempat. Yang ketiga adalah Manajemen Komunikasi Pariwisata yang membahas bagaimana manajemen diterapkan dalam bidang komunikasi pariwisata, yaitu bagaimana memenej pemasaran pariwisata, memenej destinasi, memenej aksesibilitas, dan memenej SDM serta kelembagaan pariwisata. Yang keempat, adalah tentang penyediaan akses ke tempat wisata yaitu dalam Komunikasi Transportasi Pariwisata. Kajian ini menyangkut tentang alat dan jenis transportasi, anggaran yang diperlukan, masalah keamanan dan keselamatan transportasi, transportasi alternatif dan konektivitas dengan akomodasi (hotel, motel, guesthouse). Kajian ini biasanya menggunakan model-model komunikasi alternatif seperti word of mouth, media sosial dan media lainnya. Yang kelima adalah Komunikasi Visual Pariwisata, bergerak dalam bidang desain grafis dan biasanya diterapkan pada industri kreatif yang dapat menghasilkan cinderamata, souvenir, dan oleh-oleh lain yang berkesan dan menjadi brand pariwisata. Yang keenam adalah Komunikasi Kelompok Pariwisata, yang fokus pada perilaku orang, menyangkut kemampuan pribadi pelaku pariwisata baik pemilik destinasi, penguasa venue atau bahkan kemampuan pribadi pramuwisata dan pandu wisata (penguasaan sejarah, kemampuan bertutur). $\quad$ Yang ketujuh adalah Komunikasi Online Pariwisata, kajian ini memiliki beberapa kemampuan, seperti menyimpan (upload) informasi, mengolah informasi, mengeluarkan informasi (download), menyebarkan komunikasi dan kemampuan mengkonstruksi citra informasi. Yang kedelapan adalah Public Relations dan MICE, Kajian ini membahas mengenai perencanaan dan perumusan 
program MICE (meeting, insentif, conference, exhibition), masalah funding explore, sponsorship, pemasaran MICE, akomodasi MICE sampai dengan pelaksanaan, evaluasi dan perencanaan event MICE. Dan yang terakhir adalah Riset komunikasi pariwisata dapat mengambil objek-objek riset pada bidangbidang kajian komunikasi pariwisata

Seluruh kegiatan yang dilakukan oleh industri pariwisata perlu didukung lewat kajian-kajian komunikasi pariwsata. Salah satu peran dari Jurnalisme Perjalanan adalah membantu industri pariwisata melakukan Brand Destination. Indonesia sebagai negara kepulauan tentu menawarkan beragam pesona wisata alam seperti pantai, gunung, lembah, hutan. Namun belum dikelola dengan maksimal, baik mendapatkan perhatian dari pemerintah pusat maupun dikembangkan oleh pemerintah daerah. Sejak tahun 2016, sudah ada '10 Bali Baru', sebuah makna kiasan agar setiap obyek wisata lain yang dipromosikan pemerintah bisa menyamai Bali yang setahun bisa mendatangkan jutaan wisatawan (liputan6.com, 2016). Ini menjadi tantangan bagi jurnalisme perjalanan bahwa di satu sisi harus memberitakan hal yang baik demi membantu branding destinasi wisata, namun di sisi lain juga perlu menyampaikan tentang kelemahan dari destinasi wisata tersebut agar menggugah perhatian masyarakat dan pemerintah.

Peluang bagi Jurnalisme Perjalanan untuk mendukung industri parwisata mengkomunikasikan pariwisata di Indonesia, karena masih tersedianya beragam topik yang bsia ditulis. Sumber daya Alam Indonesia yang menawarkan gunung, pantai, lautan, sabana, hutan, yang indah, yang bisa diproduksi dalam liputan visual yang mampu menggambarkan keindahan alam bagi para penontonnya, sehingga bisa menggugah keinginan untuk berkunjung(Arismunandar, 2010). Beragamnya kebudayaan di Indonesia, menjadi catatan perjalanan yang indah bila ditelusuri dan dikemas dalam liputan Jurnalisme Perjalanan. Mulai dari ritual keagamaan, adat istiadat masyarakat setempat, tarian tradisional, bangunan tradisional, adat kematian, adat perkawinan, dan masih banyak lagi. Beberapa tujuan wisata di Indonesia, memiliki masyarakat dengan kearifan lokal yang sangat kuat. Salah satunya Bali, di saat masa pandemi covid-19 berhasil membuat aturan 'jaga jarak fisik' ditegakkan dengan baik lewat pendekatan dengan kearifan lokal masyarakat Bali (teguh, 2020). Informasi ini perlu diangkat lewat konsep Jurnalisme Pariwisata, 
daripada sekedar menggambarkan tentang keindahan Bali yang sudah dikenal banyak

\section{PENUTUP}

Kehadiran teknologi baru menjadi salah satu tantangan untuk profesi sebagai jurnalis perjalanan untuk berkembang. Peluangnya adalah dengan adaptasi, inovasi, dan kreativitas agar tidak ketinggalan. Konsep jurnalisme perjalanan bisa dikembangkan dan diajarkan pada para penulis amatir sehingga menjadi bekal untuk menulis dengan konsep yang benar. Sementara untuk menang dalam persaingan yaitu dengan memanfaatkan seluruh media yang dihasilkan dari perkembangan teknologi. Poduksi konten bukan hanya lewat media cetak, tetapi lewat media elektronik, bahkan adaptasi media online. Tantangan lain adalah komersialisasi media yang berbenturan dengan etika jurnalistik. Ada celah yang bisa menjadi peluang bagi Jurnalisme Perjalanan dalam menghadapi tantangan mengenai etika dan konflik kepentingan dan komersialisasi media. Jurnalisme Perjalanan bisa dikemas selain memberikan petunjuk dan saran yang akurat terkait destinasi wisata, dipadukan dengan informasi yang kental unsur hiburan dan relaksasi. Jadi bukan sekedar memberikan informasi sesuai dengan orang.

kondisi nyatanya, tetapi membuat kemasannya lebih menarik, menghibur, dan berguna bagi publik, dan menarik sponsor atau iklan.

Jurnalisme Perjalanan dengan tantangan yang masih dipandang sebagai bagian 'abu-abu' dari Jurnalistik, sehingga belum banyak kajian atau riset yang dilakukan, masih banyak hal yang bisa dikembangkan. Ini menjadi tantangan bagi jurnalisme perjalanan bahwa di satu sisi harus memberitakan hal yang baik demi membantu branding destinasi wisata, namun di sisi lain juga perlu menyampaikan tentang kelemahan dari destinasi wisata tersebut agar menggugah perhatian masyarakat dan pemerintah. Peluang bagi Jurnalisme Perjalanan untuk mendukung industri parwisata mengkomunikasikan pariwisata di Indonesia, karena masih tersedianya beragam topik yang bsia ditulis. Terlebih lagi jika dikaitkan dengan kondisi pariwisata secara global yang ikut mempengaruhi turunnya jumlah wisatawan ke Indonesia di saat situasi merebaknya wabah Covid 19. Salah satu usaha untuk sustainable tourism adalah dengan memastikan bahwa setiap obyek wisata di 
Indonesia masih tetap ada, terawat, dan terjaga pelayanan kebersihannya. Dibutuhkan kerjasama dari berbagai pihak, termasuk didalamnya peran Jurnalis Perjalanan yang secara profesional menghasilkan liputan terntang kondisi pariwisata di Indonesia, untuk mengingatkan secara berkelanjutan tentang destinasi wisata di Indonesia.

\section{DAFTAR PUSTAKA}

Arismunandar, Satrio. (2010). Mengenal Jurnalisme Perjalanan (Travel Journalism) dan Program Jelajah. http://satrioarismunandar6.blogspot.co $\mathrm{m} / 2010 / 05 / j u r n a l i s m e-p e r j a l a n a n-$ travel-journalism.html

Bungin, Burhan. (2015). Komunikasi Pariwisata dan Brand Destinasi. Kencana Pranada. Jakarta.

Glossary of Tourism Terms. https://www.unwto.org/glossarytourism-terms

Hadi, Ido Prijana. (2009). Perkembangan Teknologi Komunikasi dalam Era Jurnalistik Modern. Jurnal Ilmiah Scriptura, Vol. 3. Januari 2009. 63 84.

Hanusch, Folker. Elfriede Fursich. (2014). Travel Journalism : Exploring Production, Impact, and Culture. Palgrave Macmillian. UK.

Hidayat. Wicak. (2014). Travel Bloger Indonesia. https://tekno.kompas.com/read/2014/0
8/13/10110067/17.Travel.Blogger.Ser u.Indonesia

Ini dia 10 Destinasi Wisata yang Disebut Bali Baru. (2016). https://www.liputan6.com/lifestyle/rea d/2445931/ini-dia-10-destinasi-wisatayang-disebut-bali-

baru\#: :text=Sepuluh\%20destinasi\%2 0pariwisata\%20yang\%20menjadi,Wa katobi\%20(Sulawesi\%20Tenggara)\%2 $\mathrm{C} \% 20$ dan

Irwansyah, Ade. (19 Januari 2019). 5 Travel Writers Indonesia yang Bikin Kamu Melek Makna Travelling Sesungguhnya.

https://www.gramedia.com/blog/travel -writer-indonesia-bikin-melek-maknatraveling-sesungguhnya/

Jalan-jalan ke Pasar Bunga Rawa Belong di Jakarta, Buka 24 Jam. (Februari 2020).

https://travel.kompas.com/read/2020/0 2/05/150000027/jalan-jalan-ke-pasarbunga-rawa-belong-buka-24-jam-dijakarta?page $=$ all

McDougal, Curtis D. (1002). Interpretative Reporting. MacMillan Publishing Co. Inc. New York.

Oetama, Jacob. (2001). Pers Indonesia Berkomunikasi dalam Masyarakat Tidak Tulus. Percetakan PT Gramedia. Jakarta.

Pendit, Nyoman S. (2003). Ilmu Pariwisata Sebuah Pengantar Perdana. Pradnya Paramita. Jakarta.

Rosenkranz, Tim. (March 2016). Becoming Entrepreneurial : Crisis, 
Ethics, and Marketization in the Field of Travel Journalism. The New School for Social Research, Departement of Sociology, United States. 54- 65.

Setyawan. Andri. (2019). Dongkrak Devisa dengan Pariwisata. .https://analisadaily.com/berita/arsip/2 019/5/28/744035/dongkrak-devisadengan-pariwisata/

Spillane. James, J. (1994). Pariwisata Indonesia: Siasat Ekonomi dan Rekayasa Kebudayaan. Yogyakarta. Kanisius.

Sunarto, (2015). Travel Journalism Berkontribusi Besar Untuk Pariwisata Indonesia.

https://travel.detik.com/travel-news/d2922996/ternyata-travel-journalismberkontribusi-besar-untuk-pariwisataindonesia

Tazbir, (2015). Travel Journalism Berkontribusi Besar Untuk Pariwisata Indonesia.

https://travel.detik.com/travel-news/d2922996/ternyata-travel-journalismberkontribusi-besar-untuk-pariwisataindonesia

Teguh. Frans. (Mei, 2020). The Future of Tourism and Hospitality Business Model in The New Normal: Opportunity for Resilience and Sustainable Tourism. Dipresentasikan dalam Seminar Pariwisata Indonesia Pasca Covid-19. Peran Penting SDM dalam Pariwisata Berkelanjutan. Magister Pariwisata. Universitas Pelita Harapan. Jakarta.
Tiede. Rachel, M. (2017). The Importance of Travel Journalism. Department of Journalism. Texas Christian University. Fort Worth. Texas.

Wibowo. Agustinus. (2014). Profile. https://agustinuswibowo.com/profile/ 